DOI: 10.31392/NPU-nc.series14.2019.27.27

УДК: 370.036-373.67

Юй Хенюань

\title{
Особливості формування вокально-виконавської майстерності китайських співаків у Китаї та в українських закладах вищої освіти
}

\begin{abstract}
Розглядається специфіка системи вокальної освіти, яка склалася в Китаї у процесі оволодіння національно-типовими формами вокального музикування. Розглянуто історичні джерела формування національної китайської вокальної школи у жанрах професійного та народного вокального мистецтва. Висвітлено особливості вокальної техніки, яка формується у артистів Пекінської опери та співаків виконавців китайських народних пісень. Увагу приділено проблемам, які постають перед китайськими науковцями у визначенні подальших шляхів удосконалення вокального мистецтва та системи підготовки співаків, що зумовлюються потребами суспільства у засвоєнні світових культурних надбань та збереженні національних мистецьких традицій. Розглянуто особливості оволодіння китайськими співаками вокальної техніки західного академічного співу та оволодіння майстерністю вокального виконання світової спадщини різних епох і стилів. Узагальнено типові проблеми, які виникають у китайських студентів у процесі навчання співу і мають вирішуватися під час їхньої професійної освіти в Україні.
\end{abstract}

Ключові слова: вокальна школа; китайські студенти; методика вокальної підготовки.

Актуальність проблеми визначена входженням української освітньої системи до світового процесу створення єдиного інформаційного й освітнього простору на засадах розширення міжнародних контактів, міжкультурного діалогу та взаємозбагачення національних освітніх систем, а також зростанням потягу студентів з Китаю до отримання вокальної професійної підготовки в українських закладах вищої освіти.

В декларації ЮНЕСКО (Мехіко, 1998 р.) зазначається що культурна самобутність народів оновлюється і збагачується внаслідок контактів з традиціями і цінностями інших народів, в діалозі думок і досвіду, осягненні цінностей і традицій інших культур. Отже, вирішення цих завдань у галузі музичного мистецтва диктує необхідність поєднання завдань розвитку i збереження національної української культури із вирішенням питань інтернаціоналізації освіти. Ці завдання постають наразі і перед українською вокально-педагогічною спільнотою, вирішення яких потребує зосередження уваги викладачів на двох методичних векторах, які передбачають підготовку власних національних кадрів та надання якісних освітніх послуг іноземним студентам, метою навчання яких за межами власної країни є підготовка до майбутньої професійної діяльності на Батьківщині.

Питання вокально-виконавської майстерності та методичні засади формування вокальної техніки у виконанні творів різних стилів досліджували В. Антонюк, Л. Василенко, Н. Овчаренко, Г. Стасько, В. Стахевич, С. Sadolin, B. Stühlmayer, G. Hoffmann, W. T. Fitch and J. Geed та ін. [2;11; 12;13]. Особливості підготовки китайських студентів до вокальнопрофесійної діяльності у закладах вищої освіти в України та Китаї висвітлено в працях Ду Сивея [3], Н. Кьон, Лоу Яньхуа [5], Ян Бо [9], Шень Сян [14] та ін. Особливості становлення китайської вокальної школи в різні історичні періоди і шляхи взаємодії національної та європейської тенденцій у розвитку вокально освіти Китаю розглянуто в працях таких науковців, як М. Антошко [1], Лю Баося [6], Сун Янін [7], Яо Вей [10 ]та ін.

Натомість специфіка формування вокально-виконавської майстерності у китайських студентів $з$ погляду особливостей їхнього попереднього мистецько-культурного досвіду та вокально-виконавської підготовки в українських закладах вищої освіти на цей час ще не ставала предметом спеціального дослідження.

Мета статті - здійснити аналіз особливостей попереднього вокально-слухацького досвіду та вокально-виконавської підготовки китайських абітурієнтів з метою їх врахування у вокально-освітньому процесі під час навчання в українських закладах вищої освіти. 
Методологічною основою дослідження $\epsilon$ ретроспективно-аналітичний підхід, який дозволяє виявити характерні особливості методики підготовки співаків до виконання національних вокальних жанрів, а також компаративний підхід, на засадах якого здійснюється порівняння європейського системи вокальної підготовки та пошуки сучасних фахівців КНР у процесі вироблення техніки китайського бельканто.

Аналіз стану підготовленості китайських студентів до отримання професійної вокальної освіти засвідчив, що вони відрізняються поміж собою за ерудованістю в галузі світового вокального мистецтва, різноманіттям художньо-емоційних станів, які вони здатні втілити у процесі співу, фонаційно-технічною оснащеністю, якістю володіння основоположними вокально-виконавськими навичками - вокальним диханням, звукоутворенням, звуковедіння тощо.

Виклад основного матеріалу. Попередні опитування і анкетування студентів дозволи висунути припущення, що ці відмінності породжені особливостями стихійно та цілеспрямовано набутого досвіду сприйняття китайськими студентами здобутків національної вокальної спадщини та особливостями методики їх навчання співу в рідній країні. Це пояснює важливість надання уваги питанням специфіки китайської вокальної культури та вокально-освітньої системи, які мають враховуватися в процесі їхньої вокальновиконавської освіти в Україні.

Оглядовий аналіз праць, в яких розкриваються особливості професійної вокальної освіти в стародавньому Китаї, дозволив виявити наявність цілісної й продуманої системи підготовки співаків, яка базувалась на філософсько-теоретичних положеннях, комплексі педагогічних методів і порад, що передавались з покоління в покоління. Надзвичайно важливо, що система музичного виховання, вважаючись заставою морального виховання «досконалої людини», вкоренилася як у народних традиціях, так і навчанні професійному співу. Стійкість традицій китайської музики дослідники пояснюють також тим, що музичному мистецтву за часів Конфуція відводилась незамінна роль в організації суспільства: музика визнавалась важливою складовою дійсності, яка активно ії формує: відповідно світогляду, філософським ідеям і релігійним уявленням китайського народу, вокальне мистецтво і пісня - це дари Неба, засновані на загальних законах всесвіту.

Як зазначають Хоу Цзянь, Т. Корягина та інші науковці, ставлення конфуціанства й китайської держави до музики як фактору впливу на виховання й суспільний устрій було безпрецедентним в історії цивілізацій і заклало одну з основних специфічних рис китайської цивілізації. Поєднання конфуціанства 3 ідеями даосизму i буддизму склало базис філософсько-естетичних та етичних уявлень китайського суспільства, духовну ауру Китаю, яка, акумулюючись в музичному середовищі, втілювалась в особливостях художнього мислення, стилістичній, жанровій та образно-тематичній палітрі музикування, цілеспрямованій увазі до методики підготовки фахівців-музикантів [4; 8].

Ретроспективний аналіз освітньо-співацьких здобутків Китаю свідчить, що вони нараховують більше 3000 років: починаючи з XIV ст. до н. е. (династія Шан), спів, гра на інструментах і танець стали частиною палацового життя, тому в країні почали діяти перші в світі вокальні музичні школи та музичні академії, зокрема - «Юе Fu», «Лі юань», «Тай Чанг Шу». У цих закладах готували співаків та музикантів-інструменталістів для участі в церемоніальних і релігійних дійствах, виконання культової та палацової (яюе) [8; 9].

Іншим джерелом співацького мистецтва була народна музика (суюе), зокрема - пісня. Уяву про багату пісенно-творчу спадщину китайського народу дає перше в історії людства зібрання 305 пісень та віршів, записаних у XI - VIII віках до нашої ери у славнозвісній книзі «Шицзин» («Книзі пісень»), які сповнені поетичних художніх образів, щирості й задушевності, емоційної яскравості й різнобарвності відчуттів, мистецька цінність котрих не загубила своєї значущості до тепер. Традиційною особливістю виконання народних пісень було їх поєднання 3 танцювальними рухами та використання усталених прийомів зовнішнього виразу характеру творів, зокрема - особливих рухово-символічних елементів, 
жестів, атрибутики (кольорові парасольки, шарфи, віяла тощо), в результаті чого пісні майже перетворювались у театралізовану виставу [8].

Відповідним чином будувалась і методика підготовки виконавців: увага учнів-початківця зверталась на важливість поєднання вокальних і рухових прийомів, аналізу й поясненню їм сутності і характеру музичних образів, вмінню супроводжувати спів рухами рук і тілом 3 метою відтворення цілісного характеру твору: адже, за уявленнями того часу, слухачі $\epsilon$ одноразово і глядачами, і вони мають насолоджуватись не тільки співочим звуком, а й вишуканими, відточеними рухами, що дасть їм вищу видовищну насолоду.

Впродовж довгого періоду склалися і музично-мовленнєві особливості китайського народного мелосу, а саме - пентатонічна одноголосна основа, широкий мелодичний діапазон, гнучка, рухлива звуковисотна лінія з типовими стрибками на чисті кварти й квінти між різними ладовими ступенями, мелодичною мелізматикою і глісандо, як необхідних прийомів адекватної передачі особливостей інтонування ієрогліфів; властиві народним мелодіям також несиметрична структура фраз; різноманіття примхливих ритмових малюнків тощо. Доречно також нагадати, що народно-пісенна творчість одноголосна, але не завжди а'капельна: спів нерідко підтримувався інструментальним унісоном та ритмово-тембровим супроводом [9].

Надзвичайно важливо, що основу старовинної китайської вокальної педагогіки становило розуміння співу як процесу індивідуального самовираження, створення власного унікального світу. Як свідчать історичні літописи, старі майстри ставили за мету «виростити особистість», розвинути іiі індивідуальні риси та розкрити потенційні можливості, знайти гармонію між типовими вокальними навичками та прийомами їх формування, характерними для певного виконавця.

Різновидом вокального мистецтва став спів як складова частина синкретичного мистецтва, зокрема - започаткованої в XII столітті складної, багатожанрової музичнодраматичної вистави, в якій поєднуються театралізоване дійство, спів, танець, акробатика, бойові мистецтва, майстерність гриму й костюму, відомої під назвою «національна китайська опера». Набуття наприкінці XVIII ст. творами цього жанру зрілих форм здобуло назву «Пекінська опера» («цзинцзюй»), яка стала цінним мистецьким здобутком китайського народу, в якому яскраво і всебічно розкриваються особливості його світогляду, художньої ментальності, мистецьких уявлень та своєрідність музичного мовлення. Основу цього жанру складає традиційний комплекс сюжетів, пов'язаних з реальними історичними подіями, а його музичне оформлення створюється на основі двох типів народних наспівів, які виконавці мають самі варіювати й компонувати в процесі розгортання дійства, відповідно своїм індивідуальним можливостям. При цьому саме імпровізаційно-індивідуальний внесок актора складав своєрідність вистави на один і той же сюжет: зміна складу виконавців створювала інший спектакль [8].

Важливо, що герої всіх спектаклів - це типові персонажі-маски, 3 властивим їм характером, типом голосу та манерою виконання. Отже, артист має відповідати амплуа, яке йому пасує i доводити свою майстерність до досконалості, дотримуючись усталених критеріїв якості звучання голосу в декламації та специфічно-виразному співі. 3 метою оволодіння співака певним амплуа застосовуються різноманітні методики, наприклад «кричуще» горло, вправи для тренування зміни типу звукобудування, різкої зміни висоти звуків тощо [8].

Отже, до XIX століття в музичному житті країни панували дві форми вокальної діяльності - виконання народних пісень та спів як складник театральної вистави, оволодіння якими відбувалось на усталених методичних принципах і методах навчання виконавців.

Розглянемо тепер процес становлення вокально-виконавського мистецтва Китаю, зорієнтованого на опанування здобутків Західної музичної культури. Їх активне засвоєння в китайському суспільстві розпочалося з кінця XIX - початку XX століть у зв'язку із змінами, що відбулися в суспільному устрої країни та новій політиці культурної відкритості і розширення мистецьких контактів між Сходом і Заходом. Завдяки цьому музичне життя 
китайського суспільства збагатилось враженнями від вокально-камерного, багатоголосного хорового та симфонічного мистецтва, творів оперного жанру європейського зразка. Крім того, талановита китайська молодь, зокрема - видатні музиканти того часу Сяо Юймей, Чжоу Шуань, Хуан Юкуй, Юй Ісюань, Лан Юйсю, Чжао Мейбо та ін., отримали змогу навчатися в Європі [1; 14]. Повернувшись у свою країну, ці музиканти стали фундаторами музичноосвітніх закладів нового типу, а саме - першої в КНР Шанхайської національної консерваторії, відкритої в 1927 році, дещо пізніше - школи оперних співаків у Шанхаї та Цинані, відділу оперного виконавства в Пекінському університеті, навчання в яких здійснювалось за навчальними планами, підручниками, репертуаром відомих світових музично-освітніх закладів.

Поява нових тенденцій в сфері вокального мистецтва і освіти поставила перед китайськими музичними діячами складне завдання - визначити курс оновлення національного вокального мистецтва 3 орієнтацією на різні вектори розвитку. Це стало предметом наукової дискусії між фахівцями: одні вважали головною метою освіти підтримку й збереження національного співочого мистецтва, інші виступали прихильниками методів, заснованих на традиціях бельканто, треті вважали доцільним створення нової методики, побудованої на врахуванні європейських традицій та їх поєднанні з принципово важливими для національного мистецтва особливостями китайської вокальної техніки.

Значу роль у справі суміщення усталених національних технік і техніки, побудованої на традиціях бельканто, відіграли діяльність білоруського викладача вокалу В. Шушліна, (Су Ши Лин) та його послідовників - Шень Сяну і Го Шучжень, які виховали кілька поколінь китайських співаків світового рівня [6].

Плідні пошуки в цьому напрямку здійснювалися також в Академії імені Лу Сіня: саме тут було вироблено особливий, притаманний виключно китайським співакам, оперно-пісенний стиль, що поєднував народний спів, техніку співаків Пекінської опери та елементи європейської вокальної школи [8]. Показово, що в цій академії колективом студентів було створено на основі народних наспівів і традицій західної опери один з перших творів нового стилю - оперу «Сива дівчина».

Виділяють науковці також діяльність вченої і викладача вокалу Чжоу Сяоянь, яка засвоїла італійські, російські, французькі основи вокальної освіти і активно пропагувала методи застосування бельканто у підготовці китайських співаків, що, на іiі думку, мало сприяти формуванню навичок «прикритого» способу звукобудування, природності і щирості виконання, виробленню приємного й виразного тембру, Як зазначає Ян Бо, «...багато в чому iiі методика ламала стереотипи, що склалися і рутинні теорії, що панували у вокальній освіті» $[9$, c.132].

На цей час у Китаї питання розвитку системи вищої вокальної освіти залишаються дискусійними. На думку таких фахівців, як Пан Чунжун, Яо Ямін, Яо Вей та ін., негативну роль відіграє низька якість вокальній освіти, яку співаки отримують у закладах середньої професійної ланки, недостатня кількість вищих навчальних закладів, в яких співаки отримують ступінь спеціаліста та бакалавра 3 музичних спеціальностей (їх кількість за музичним профілем складає біля 160, і всього у 100 з них можна отримати музичнопедагогічну освіту). Серйозній критиці підлягають навчальні плани цих закладів, у яких на індивідуальні заняття співом відводиться тільки 2 годин на тиждень [10]. Відзначається і нестача у вищих закладах високопрофесійних викладачів з вокалу, що негативно впливає на якість вокально-професійної підготовки студентів, зокрема - i тих, що оволодівають вокально-викладацькою професією в Україні.

Висновки. Головними недоліками цієї освіти, на думку українських фахівців, $\epsilon$ недостатня вокально-стильова база і слуховий досвід китайських студентів; низький рівень музично-теоретичної підготовки, що заважає китайським студентам самостійно аналізувати музичний текст, виявити особливості мелодії, гармонічної мови і фактури акомпанементу, розучувати вокальні твори та їх інтерпретувати. Крім того, значну складність для китайських 
студентів становить оволодіння навичками вокальної артикуляції тексту на різних мовах та усвідомлення сутності художнього сенсу вокальних творів в єдності вербально-поетичного та інтонаційно-мелодійного складників їх цілісного образу.

Визначення автором типових проблем, які виникають у китайських студентів-вокалістів важливе підгрунтя удосконалення методики вдосконалення їхньої підготовки у педагогічних університетах України до викладання вокалу у системі вищої освіти Китаю.

\section{Література}

1. Антошко M.O. (2019). Розвиток музичної освіти у Китаї на початку XX. DOI: https://doi.org/10.32839/2304-5809/2019-9-73-30

2. Голос людини та вокальна робота 3 ним : монографія. (2010). Г. Є. Стасько, О. Д. Шуляр, М. Ю. Сливоцький та ін. Видавництво Прикарпатського національного університету імені Василя Стефаника, Івано-Франківськ. 336с.

3. Ду Сывэй. (2008). Формирование певческих умений у вокалистов в высших учебных заведениях КНР. Дис... канд. пед наук. Москва.

4. Корягина Т.О. (2019). Репрезентация диалога «Человек - Природа» в философии древнего Китая. Том 12. Выпуск 5. Манускрипт, Чита. 139-143с.

5. Кьон Н.Г., Лоу Яньхуа. (2018). Досвід формування вокально-орфоепічної культури іноземних магістрантів у процесі підготовки до фахової діяльності. Актуальні питання мистещької освіти та виховання. Вип. 2. Суми, 141-149c. Режим доступу: http://nbuv.gov.ua/UJRN/apmov_2018_2_16

6. Лю Баося. (2016). В.Г. Шушлин и вокальное образование в Китае. Материальл ХІХ Международной научно-практической конференции «Управление в соичальной и экономической системе», Минск. 381-382c.

7. Сун Яньін. (2016). Музична освіта в китайській народній республіці в другій половині століття. Наукові збірки Львівської національної музичної академії ім. М. В. Лисенка. Вип. 32. 7180 c. http://nbuv.gov.ua/UJRN/Nzlnma_2014_32_10.

8. Хоу Цзянь. (2010). Художественный мир китайской народной оперы: монография. [за ред. В.Г. Антонюк]. ПВД «Твердиня», Луцк. 100 с.

9. Ян Бо, (2016). Чжоу Сяоянь: у истоков профессионального певческого искусства Китая. Актуальные проблемы высшего музыкального образования. Нижнегор. гос. консерватория им. М. И. Глинки. 1 [39], Нижний Новгород. 57-60с.

10. Яо Вэй. (2012). Проблемы развития вокального профессионального образования в современном Китае. Дискуссия, № 7 (25), 150-154c.

11. Sadolin C. (2000) Complete Vocal Technique. Copenhagen: Shout Publications.

12. Stühlmayer, B. Hoffmann, G. (2017). Stimme-Be-Stimmung. München, Verlag DeBehr. 103 p.

13. W. T. Fitch and J. Giedd. (1999). Development of the human vocal tract. The Journal of the Acoustical Society of America. DOI: 10.1121/1.427148 Source: PubMed CITATIONS 587

14. Шэнь Сян. (1996). Система воспитания академического пения. Пекин : Пекинская Центральная консерватория музыки, 149 с. (китайською)

Про автора:

Юй Хенюань, аспірант Південноукраїнського національного педагогічного університету імені К. Д. Ушинського (65020 Одеса, Україна); ORCID: 0000-0001-8817-4547

\section{Features of formation of vocal and performing skills of Chinese singers in China and in Ukrainian higher education institutions}

Relevance of the study. The article considers peculiarities of professional singing education, the foundation for which was laid in ancient China and outlines the possibility of their incorporation into the process of developing European style singing technique, which is relevant for the development of Chinese vocal art and improvement of the training of Chinese students in Ukraine.

The purpose of the article is to analyze the peculiarities of previous singing and listening experience, singing and performance training of Chinese university applicants in order to include them in the singing educational process while studying at Ukrainian higher education institutions. 
Literature review. Various aspects of the peculiarities of Chinese students' preparation for vocal and professional activity in higher educational establishments of Ukraine were researched by N. Koehn, Lou Yankhua, Zhang Yanfen and others. Problems of modern vocal education in People's Republic of China and ways of national and European tendencies interaction in the development of vocal education in China were considered by Liu Baosia, Yang Bo, Wu Yifang, Shen Xiang.

Research methods. Methodological basis of the study lies in the retrospective analytical approach, which allows to reveal the features characteristic to the methodology of preparing singers for the national vocal genres performance, as well as in the comparative approach, on the basis of which a comparison of the European vocal training system and the search for modern specialists of China in the process of Chinese bel canto technique development is performed.

Results. The author characterizes peculiarities of the folk song genre and the genre of the Beijing opera, as well as specifics of vocal and technical skills in the following genres: vocal breathing with support for the lower abdomen, involvement of the cranial and nasal resonators, singing in a high vocal formant, combined with neutral palate position, which brings to a glide nasal sound and a "flat", sharp sound. Characterization is given to the new trends that emerged in the late XIX century in the field of Chinese vocal art in connection with a new cultural openness policy, a focus on updating national vocal art based on European traditions and combining them with specific features of Chinese vocal techniques. The range of tasks that require special attention in the process of teaching Chinese students at Ukrainian pedagogical universities is identified: expansion of vocal and stylistic basis; enrichment of auditory experience and ability to analyze and interpret vocal works independently; improvement of skills to solmizate and self-mastering the musical text of the work, its comparison with the accompaniment part; ability to analyze texture, features of harmonious language; stimulation of artistic thinking and creative activity independence, mastering the skills of articulation of works in foreign languages, the need for vocal and technical skills restructuring, in particular sound formation techniques, formation of high vocal position, involvement of all resonators, mastering legato singing skills.

Discussion. The author considers the features of the modern higher vocal education system in China and the disadvantages manifested in insufficient number of specialized educational institutions, the limitation of the curriculum, the amount of hours allocated for individual vocal classes, the lack of highly professional singing teachers, which in general results negatively on the quality of bachelor students' professional vocal training.

Novelty. Outlines typical difficulties that Chinese master degree students face in the process of vocal and performing skills mastering at Ukrainian pedagogical universities. These difficulties relate to the problems of adaptive and psychological, generally cultural character (entering a different cultural environment), insufficient level of theoretical musical, instrumental, artistically performing and vocally technical training.

Conclusions. Singing teachers of Ukrainian educational institutions must be aware of the existing differences between European and Chinese methods of teaching singing, and this awareness should facilitate a deeper understanding of the problems faced by Chinese university applicants and the development of effective methods for overcoming those problems.

Significance. The solution of the outlined problems should contribute to increase of the Ukrainian vocal school competitiveness under the conditions of the world educational space internationalization, as well as to improve the vocal and performing artistry of Chinese singers.

Keywords: system of vocal education; Chinese students; methods of vocal training.

\section{References}

1. Antoshko M.O. (2019). Rozvytok muzychnoyi osvity v Kytayi na pochatku XX. [Peculiarities of development Chinese singers' vocal and performing artistry in China and in Ukrainian higher education institutions]. DOI: https://doi.org/10.32839/2304-5809/2019-9-73-30 [in Ukrainian].

2. Holosova lyudyna ta vokal'na robota $\mathrm{z}$ nym: monohrafiya. [Human voice and its vocal training: a monograph]. (2010). H. YE. Stas'ko, O. D. Shulyar, M. YU. Slyvots'kyy ta in. Vydavnytstvo Prykarpats'koho natsional'noho universytetu imeni Vasylya Stefanyka, Ivano-Frankivs'k. pp. 336. [in Ukrainian].

3. Du Syvéy. (2008). Formirovaniye pevcheskikh umeniy v vokalistov v vysshikh uchebnykh zavedeniyakh KNR [Formation of vocalists' singing skills in higher educational institutions of the People's Republic of China]. Moscow. [in Russian]. 
4. Koryahina T.O. (2019). Reprezentatsiya dialoha «Chelovek - Pryroda» u filosofiyi drevneho Kytaya [Representation of the dialogue "Man and Nature" in the philosophy of ancient China]. Manuskrypt, Chyta. Tom 12. Vypusk 5. pp. 139-143. [in Russian].

5. Koehn N.H., Lou Yan'khua. (2018). Dosvid vykorystannya vokal'no-orfoepichnoyi kul'tury zarubizhnykh mahistrantiv pid chas navchannya do fakhovoyi diyal'nosti [Experience of development foreign master degree students' vocal orthoepic culture in the process of training for professional activity]. Aktual'ni pytannya mystets'koyi osvity ta pidvyshchennya rivnya. Vyp. 2. Sumy, 141-149. URL http://nbuv.gov.ua/UJRN/apmov_2018_2_16. [in Ukrainian]

6. Lyu Baosya. (2010). V.H. Shushlin i vokal'noye obrazovaniye v Kitaye. [V.H. Shushlin and vocal education in China]. Materialy XIX Mizhderzhavna naukovo-praktychna konferentsiya «Upravlinnya sotsial'no-ekonomichnoyu systemoyu», Mins'k, pp. 381-382. [in Russian].

7. Sun Yan'in. (2016). Muzychna osvita v kytays'kiy narodniy respublitsi v druhiy polovyni stolitta. [The artistic world of Chinese folk opera: a monograph]. Naukovi zbirky L'vivs'koyi natsional'noyi muzychnoyi akademiyi im. M. V. Lisenka. Vyp. 32. PP. 71-80. http://nbuv.gov.ua/UJRN/Nzlnma_2014_ 32_10. [in Ukrainian].

8. Khou Tszyan'. (2010). Khudozhestvennyy myr kytays'koyi narodnoyi opery: monohrafiya / za red. V.H. Antonyuk. PVD «Tverdynya», Lutsk, 100 p. [in Russian].

9. Yan Bo, (2016). Chzhou Syaoyan': u istorykiv profesiynoho pevnoho mystetstva Kytaya [At the Origins of China's Professional Singing Art]. Problemy vysshego muzykal'nogo obrazovaniya. Nizhnegor'ye. gos. konservatoriya im. M. I. Glinki. 1 [39], Nizhniy Novgorod. pp. 57-60.

10. Yao Véy. (2012). Problemy razvitiya vokal'noy professional'noy podgotovki v sovremennom Kitaye.. [Problems of professional vocal education development in modern China]. Obsuzhdeniye № 7 (25), pp. 150-154. [in Russian].

11. Sadolin S. (2000). Povna vokal'na tekhnika [Education system of academic singing]. Kopenhahen: Krychaty publikatsiyi.

12. Shtul'mayer B. Hofman H. (2011). Stimme - Be-Stimmung München, Verlag DeBehr [in Germany].

13. Fitch U. T. ta Dzh. Hedd. Development of the human vocal tract. The Journal of the Acoustical Society of America. DOI: 10.1121/1.427148 Source: PubMed CITATIONS. pp.587

14. Shén' Syan. (1996). Systema vospytaniya akademichnoho peniya. Pekin: Pekins'ka Tsentral'na konservatoriya muzyky, 149 p. (in Chinese)

About the author:

Yu Hengyuan, postgraduate student, K. D. Ushynsky South Ukrainian National Pedagogical University (65020 Odesa, Ukraine); ORCID: 0000-0001-8817-4547, e-mail: 1148236892@qq.com 